\title{
ATENUAÇÃO DA RADIAÇÃO SOLAR POR DIFERENTES ESPÉCIES DE PALMEIRAS E SEUS EFEITOS NO AMBIENTE TÉRMICO.
}

\author{
Rafael dos Reis Okuta*, Neusa L. S. Ribeiro, Lucila C. Labaki.
}

\begin{abstract}
Resumo
Por conta da sua estética harmoniosa, as palmeiras são muito utilizadas em projetos paisagísticos, porém, pouco se sabe a respeito dos benefícios que o vegetal pode proporcionar ao ambiente térmico. Dessa forma, nesta pesquisa serão estudados especificamente três espécies de palmeiras: Wodyetia bifurcata ("Rabo de Raposa"), Phoenix dactylifera ("Tamareira") e Washingtonia robusta ("Washingtonia"), do ponto de vista da atenuação da radiação solar e seus efeitos nas demais variáveis climáticas, como velocidade do vento, temperatura do ar, temperatura de globo, umidade relativa do ar e radiação solar. O estudo será levado a efeito nas quatro estações do ano. Com esses dados, através do cálculo dos parâmetros indicadores e elaboração de gráficos, será possível analisar sua efeciência na atenuação solar e, por fim, comparar as espécies em questão e concluir se as mesmas influenciam ou não na alteração do microclima onde estão aplicadas e, consequentemente, geram mais conforto térmico aos usuários ao local.
\end{abstract}

Palavras-chave:

Arborização urbana, conforto térmico, palmeiras.

\section{Introdução}

A implantação de espécies arbóreas em meios urbanos predominantemente pavimentados é uma estratégia antiga para amenizar a temperatura local desses ambientes, sejam eles residenciais ou comerciais. Considerando sua vasta variedade de espécies (cerca de 2700 ) e gêneros (240 no total), as palmeiras são amplamente utilizadas em fachadas, shopping centers e avenidas, devido a sua aparência tropical e seu desenvolvimento totalmente individualizado. Sabendo que o conhecimento das características de uma espécie arbórea, tal como sua arquitetura, é de extrema importância para que o plantio atinja seus objetivos esperados, decidiu-se analisar a eficiência de suas sombras no que se concerne a conforto térmico. Assim, será possível desenvolver uma base de estudo neste ramo e, posteriormente, utilizá-lo para que sejam consideradas não somente a estética, mas a sua eficiência em sombreamento em projetos paisagísticos.

\section{Resultados e Discussão}

Utilizando como base a pesquisa feita por LOYDE1, decidiu-se trabalhar também com o software Rayman PRO 2.1 (Matzarakis, Rutz \& Mayer, 2007, 2010) para o cálculo do parâmetro PET - Physiological Equivalent Temperature (MAYER; HOPE, 1987 apud HOPPE; 1999) para cada horário do dia, no período das $8 \mathrm{am}$ até às $17 \mathrm{pm}$. Dessa forma, foi possível a elaboração de gráficos que nos permitem analisar o desempenho individual de cada espécie de palmeira, como é mostrado pela Figura 1.

Além disso, a partir da Calibração de Monteiro, classificaram-se intervalos de temperatura de acordo com o conforto térmico proporcionados ao ser humano. Assim, obteve-se o resultado de que, na estação do Verão, a palmeira "Washingtonia" foi a que obteve melhor desempenho, com cerca de $26 \%$ do tempo proporcionando "Pouco calor" em sua sombra, contra 9\% da "Tamareira" e 7\% da "Rabo de Raposa".

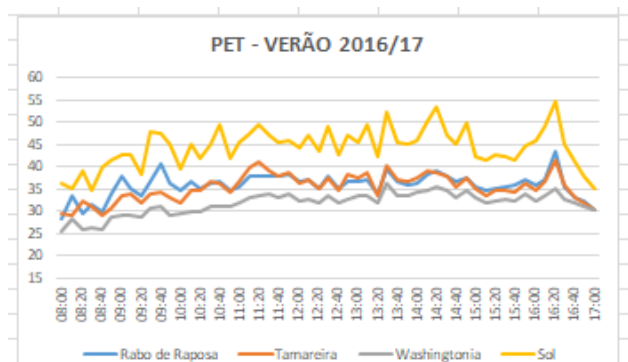

Figura 1. Cálculo do PET na estação do Verão.

\section{Conclusões}

Através de parâmetros como o PET, conclui-se que as palmeiras podem proporcionar de maneira razoável conforto térmico aos seus usuários através da sua sombra nos ambientes urbanos. Assim, deixam de ser somente um objeto de decoração para se tornar uma opção útil de sombreamento aos ambientes.

Apesar de não ter sido apresentado, nesta pesquisa obtiveram-se resultados ainda melhores quando se utilizam palmeiras agrupadas, já que as mesmas conseguem proporcionar uma maior área de sombreamento e, assim, alteram o microclima em que estão inseridas, que era um dos questionamentos iniciais do estudo.

Por fim, vale salientar que, por conta do grande número de espécies, é possível obter resultados ainda melhores que os apresentados nesta pesquisa, visto que ainda é uma área de estudo pouco explorada por pesquisas científicas em geral, provando ser uma área muito promissora para o futuro.

\section{Agradecimentos}

Ao CNPQ pelo apoio financeiro, à Lucila Labaki por todo o auxílio durante o ano, e à Neusa Ribeiro, por permitir desenvolver esta pesquisa em conjunto de seu Mestrado.

\footnotetext{
${ }^{1}$ ABREU, L. V.; LABAKI, L. C. Conforto térmico propiciado por algumas espécies arbóreas: avaliação do raio de influência através de diferentes índices de conforto. Ambiente Construído, v.10, n.4, p103-117, 2010.
} 